\title{
Imaging and Monitoring Tree-Induced Subsidence Using Electrical Resistivity Tomography
}

\author{
G.M. Jones ${ }^{1}$, N.J. Cassidy ${ }^{1}$, S. Plante ${ }^{2}$, Pringle, J.K. ${ }^{1}$ \\ ${ }^{1}$ Applied and Environmental Geophysics Group, School of Physical and Geographical Sciences, Keele \\ University, Staffordshire,UK (g.m.jones@epsam.keele.ac.uk,n.j.cassidy@esci.keele.ac.uk) \\ ${ }^{2}$ Archer Equitable Limited, Birmingham, UK (ael@blueyounder.co.uk)
}

\begin{abstract}
Tree-Induced Subsidence (TIS) is a natural ground phenomenon which arises when tree roots absorb water from clay-rich soils causing them to shrink. This is particularly prevalent for ground in proximity to deciduous trees in seasonal climates. The main geotechnical issues are a lack of understanding on the dynamics associated with the problem and the lack of a reliable and affordable assessment technology. This paper presents, and discusses the application of, 2D Electrical Resistivity Tomography (ERT), to image tree-related desiccation and the related subsidence. Repeat (time-lapse) resistivity profiles collected over two years over two high-risk TIS environments are presented and compared to conventional ground levelling and soil moisture content data.

This study confirms ERT to be a valuable tool in detecting time-varying moisture distributions around trees in clay-rich soils. Correlating the different field datasets confirm that ERT monitoring is capable of defining the time-varying extent and general architecture of an active tree root system through its affect on ground moisture. Overall the method provides a critical insight into the visualisation of the TIS phenomena and reveals promising potential for use as non-invasive and modern TIS assessment tool.
\end{abstract}

\section{Introduction}

Throughout the world, ground movement caused by moisture content variations in expansive clay soils is a major geotechnical problem. In the UK alone, the structural damage arising from ground subsidence and associated heave due to water-related volumetric changes in expansive clays is estimated to cost over $f 400$ million per annum (Jones, 2004). The principal cause of such damage in UK urban areas however, has not only been attributed to expansive clays (e.g. montmorillonite, smectite, etc.) in soils but increasingly to the influence trees have in promoting significant ground movement through soil moisture depletion. As a result, the phenomenon, often referred to as Tree-Induced Subsidence (TIS), is a concern, not only for homeowners (who can suffer both domestic property damage and the loss of troublesome, often valued trees) but insurers, developers and local Government authorities.

The diagnosis of tree-induced subsidence currently involves a multitude of specialists (ranging from geotechnical engineers, arborists and loss adjustors) to conduct numerous, largely invasive surveys, to verify that the movement and damage in question is actually tree related. Typical assessments involve determining the soil index properties (Atterberg Limits) and comparing soil water, suction, strength and ground movement profiles both away and close to the tree using single point measurements. These traditional geotechnical analysis methods however, are not only invasive (requiring boreholes), but are typically expensive, 
labour intensive, sometimes unreliable and ultimately provide a very limited understanding of tree-related subsidence, especially in the long term.

More recently, geophysical research has recognised that moisture distribution patterns relating to water-uptake by vegetation can be imaged non-invasively using Electrical Resistivity Tomography (ERT) (Barker and Moore, 1998, Panissod, et al, 2001, Conein and Barker, 2002, Al Hagrey, et al, 2004). Barker and Moore, 1998 were among the first to discover this potential following an infiltration study monitored by 2D ERT. Time-lapse resistivity profiles from the monitoring showed that significant moisture loss attributable to an Oak situated along the survey section could be observed. Since then, ERT has been used within agricultural contexts Pannisod et al, 2001, incorporated within soil-plant-atmosphere continuum models (Al Hagrey et al, 2004) and indicated (through the preliminary research of Conein and Barker, 2002), to have a direct application worth within the TIS context.

Despite the above, very little work has been done to show the potential merits of using ERT for the direct assessment of Tree-Induced Subsidence.

This paper presents and discusses the use of 2D Electrical Resistivity Tomography (ERT) in imaging and monitoring tree-related desiccation and the related ground subsidence. Monthly repeat (time-lapse) resistivity profiles collected over a two year sampling period in two typical high risk TIS environments in the U.K are presented, alongside cross-correlations with ground levelling and moisture content data. 


\section{The Study Area}

The study area lies in a recognised high risk TIS area of expansive clay rich soils within southeast England in Elstree, near Watford, U.K. (Fig.1). Within the study area two species of high water-demand trees were selected for the research, comprising an Oak (Quercus spp) on an open playing field and a Willow (Salix spp) within the confines of a domestic garden (Fig 2). Details of each tree and the surrounding sites are summarised in Table 1.

Table 1. Details of the trees and sites used in this Tree-Induced Subsidence study

\begin{tabular}{|c|c|c|}
\hline Common Name & Oak & Willow \\
\hline Species & Quercus robur & Salix spp \\
\hline Height (m) & $\sim 18$ & $\sim 14$ \\
\hline $\begin{array}{l}\text { Trunk Diameter/ D } \\
\text { (m) } \\
\text { Canopy diameter }\end{array}$ & 0.92 & 0.57 \\
\hline Age (years) & 100 ТВC & $\sim 35$ \\
\hline Setting description & $\begin{array}{l}\text { Well maintained school playing } \\
\text { field. The oak is one of a row of } \\
\text { similar-aged, } 20 \text { m-spaced } \\
\text { mature oaks which bisects the } \\
\text { grass playing field (See Fig.1c). }\end{array}$ & $\begin{array}{l}\text { Garden of a 1960s detached } \\
\text { house. The willow is situated } \\
\sim 30 \mathrm{~m} \text { from the house and } \sim 40 \\
\mathrm{~m} \text { down-slope of another } \\
\text { similar sized willow (Fig.1c). } \\
\text { Within } 10 \mathrm{~m} \text { is a flower bed } \\
\text { and } 15 \mathrm{~m} \text { to the west is a } \\
\text { young beech tree. Hedges, } \\
\text { shrubs and mixed species } \\
\text { young trees form the grassed } \\
\text { garden perimeter. }\end{array}$ \\
\hline
\end{tabular}

\begin{tabular}{llll}
\hline $\begin{array}{l}\text { Height above sea level } \\
\text { (ASL) and Local }\end{array}$ & $\begin{array}{l}93 \mathrm{~m} . \\
\text { localised hollows \& slight } \\
\text { topography }\end{array}$ & linear, north-south aligned dip. & \\
\hline
\end{tabular}

Site Hydrology $\quad$ The short-term hydrology of both sites is assumed to be dominated by surface water run-off and evapotranspiration due to the very low permeability London Clay. Surface water run-off would follow topographic gradients and therefore flow to the west and northwest for the Willow and Oak sites respectively.

* DBH (Diameter at Breast Height) derived through measuring tree girth $1.5 \mathrm{~m}$ above ground level and dividing this value by pi.

The regional geology of the study area is comprised of outcropping London Clay, which rests unconformably on vertically and laterally varying gravels, sands, silts and clays of the Lower Eocene Woolwich and Reading Beds of the Lambeth Group. The local stratigraphy of each site, as revealed by boreholes drilled in May 2006 to a depth of six metres (Fig.3 \& 4), consists of a firm-to-stiff brown clay, often containing silt veining and fine-to-medium gravel (predominantly siltstone, chert and flint). Laboratory tests conducted on borehole samples confirm the clay to be highly expansive with plasticity index values between 32 and 54 . Comparisons of soil profiles constructed from borehole data, from each testing site (Fig.4), indicate a more homogeneous clay composition at the Willow site in comparison to the clays at the Oak site which contain abundant localized, gravel rich heterogeneities. 


\section{Site Instrumentation \& Methods}

\subsection{ERT Data background, Acquisition and Inversion}

\section{ERT Background}

Electrical resistivity is a fundamental and diagnostic physical property primarily influenced by fluid content and material composition (Reynolds, 2001), that can be determined by measuring the resulting potential (voltage) difference between two electrodes when a current is induced into the sub-surface. The 2D ERT (Electrical Resistivity Tomography) method involves the measurement of sub-surface resistivity over varied lateral distances and depths to obtain a two-dimensional resistivity profile of the subsurface. The acquisition and inversion of such profiles have many engineering and environmental applications (including site characterisation, mining exploration, aquifer mapping and delineating contamination plumes) (McCann et al, 1997). Due to the highly influential nature of fluids on resistivity, the high resolution measurement scale, low error repeatability and capability to detect subtle temporal and spatial sub-surface variations, ERT is highly favoured amongst other geophysical methods for use within hydrogeological contexts. As such the method is commonly used for subsurface moisture and fluid flow investigations for example; mapping landfill leachate plumes (Zume et al, 2006), monitoring vadose zone hydrology and flow pathways (Liu and Yeh, 2004, Binley et al, 1996) and estimating moisture content and porosity (Dannowski and Yaramanci, 1999, Turesson, 2006).

\section{ERT Data Acquisition}

Two-dimensional ERT data was acquired on a monthly basis between April 2006 and July 2008 using a Campus Tigre ${ }^{\mathrm{TM}}$ resistivity meter, ImagerPro ${ }^{\mathrm{TM}} 2000$ acquisition software and two permanent linear arrays of 32 stainless steel electrodes spaced at $0.75 \mathrm{~m}$ intervals. Each array was installed $0.15 \mathrm{~m}$ below ground level (Fig.5c) and terminated into a junction box containing the array cable output for connection to the resistivity meter (Fig $5 \mathrm{~d} \& \mathrm{e}$ ).

The Wenner electrode configuration (Loke, 1998) was selected for ERT monitoring for its;

- robustness to noise

- $\quad$ moderate depth of investigation (which suited a tree root system)

- intermediate sensitivity to Near Surface Lateral Effects (NSLE), (a good compromise for resolving shallow roots whilst also minimising seasonal surface variations)

- $\quad$ high signal strength and

- $\quad$ high resolution to vertical changes (for imaging the drying effects of tree roots which are typically laterally distributed (Thomas, 2000)).

An electrode spacing of $0.75 \mathrm{~m}$ was chosen to obtain a maximum depth of investigation of approximately $4 \mathrm{~m}$ which provides suitable imaging resolutions for typical tree root and foundation depth ranges.

\section{ERT Data Inversion}

Inversion of the apparent resistivity 2D profile data to obtain true resistivity sub-surface models was carried out using RES2DINV ${ }^{\mathrm{TM}}$ inversion software which utilizes a least squares inversion code (Loke and Barker, 1996). To analyse temporal changes in resistivity both quantitatively and spatially without the interference of the background geology, the timelapse inversion method within RES2DINV ${ }^{\mathrm{TM}}$ was utilised. As changes in moisture content over 
time were expected to change in a smooth manner, a least squares inversion model constrain was utilised in conjunction with a robust data constrain to remove outlier data points and minimise noisy data effects (Loke, 1998). To reduce potentially strong near surface effects experienced during monitoring (i.e. those due to seasonal temperature variations) the model refinement option (which adjusts the model cells to half their true spacing), was also enabled.

\section{2}

\section{Traditional Conventional Geotechnical TIS Assessment Methods}

To compare ERT patterns of tree-related moisture change with clay volume change, a series of levelling stations were installed parallel to the ERT arrays for monitoring ground movement. A series of neutron probe monitoring wells were also installed at the Oak site parallel to one ERT array to collect soil moisture data for the analysis of Soil Moisture Deficits. Further details of each assessment method is summarised in Table 2.

Table 2. Details of data collected from traditional TIS assessment methods.

\begin{tabular}{|c|c|c|c|c|c|}
\hline Data & Method Rationale & Frequency & Instrument & Surveyors & Sites \\
\hline $\begin{array}{l}\text { Soil } \\
\text { Water } \\
\text { Content/ } \\
\text { Soil } \\
\text { Moisture } \\
\text { Deficits }\end{array}$ & $\begin{array}{l}\text { To measure } \\
\text { volumetric soil } \\
\text { moisture content } \\
\text { at intervals of } \\
0.25 \mathrm{~m} \text { to a depth } \\
\text { of } 3.75 \mathrm{~m} \text { in a } \\
\text { series of } \\
\text { permanently } \\
\text { installed } \\
\text { monitoring wells. }\end{array}$ & $\begin{array}{l}\text { Monthly, in } \\
\text { conjunction } \\
\text { with ERT } \\
\text { Data } \\
\text { Collection }\end{array}$ & $\begin{array}{l}\text { Wallingford } \\
\text { Neutron } \\
\text { Probe }\end{array}$ & $\begin{array}{l}\text { Derek Clarke } \\
\text { and Joel } \\
\text { Smethurst - } \\
\text { Southampton } \\
\text { University }\end{array}$ & $\begin{array}{l}\text { Aldenham } \\
\text { Oak Site } \\
\text { (See Fig. } 3 \\
\text { for } \\
\text { layout) }\end{array}$ \\
\hline $\begin{array}{l}\text { Ground } \\
\text { Levels }\end{array}$ & $\begin{array}{l}\text { To measure } \\
\text { surface ground } \\
\text { movement from a } \\
\text { linear series of } \\
\text { permanently } \\
\text { installed ground } \\
\text { rod leveling } \\
\text { stations. }\end{array}$ & $\begin{array}{l}\text { Monthly, in } \\
\text { conjunction } \\
\text { with ERT } \\
\text { Data } \\
\text { Collection }\end{array}$ & $\begin{array}{l}\text { Topcon DL- } \\
102 C \\
\text { Digital } \\
\text { Leveller }\end{array}$ & $\begin{array}{l}\text { Monitoring } \\
\text { Services Ltd }\end{array}$ & $\begin{array}{l}\text { Aldenham } \\
\text { Oak \& } \\
\text { Willow } \\
\text { Sites (See } \\
\text { Fig. } 3 \text { for } \\
\text { layout) }\end{array}$ \\
\hline
\end{tabular}

\section{Results \& Interpretation}

The data presented in this paper show selected results taken from data collected at monthly intervals from April 2006 to July 2008. Contemporary averaged temperature and rainfall for this period is shown in Figure 6.

\subsection{Temporal Monitoring Levelling Data}

Ground-levelling data from both sites, relative to a baseline month (May 2006), confirm the occurrence of significant cyclical and seasonal ground movements at both sites (Fig.7) Significant (maximum $60 \mathrm{~mm}$ and $35 \mathrm{~mm}$ for Willow and Oak sites respectively) and continuous subsidence occurred throughout each summer and the beginning of autumn. Levelling data then showed a ground movement switch from subsidence to heave, where 
again the Willow site had a greater magnitude of movement with accumulative swell (heave) of $<45 \mathrm{~mm}$ compared to values of $<30 \mathrm{~mm}$ swell for the Oak site. Both subsidence and heave could be partially attributed to seasonal temperature and rainfall variation (Fig.6). Low rainfall, high temperatures and increased evapotranspiration by vegetation (particularly by deciduous trees) during summer promoted clay-rich soil subsidence through soil moisture reduction, whereas the cessation of summer transpiration by deciduous trees and wetter soil moisture regimes caused ground rehydration, swell and recovery during autumn and winter.

Several trends in the temporal levelling data indicate the occurrence of TIS as opposed to ground movement changes due only to seasonal variations. These include the timing and rate of subsidence experienced at both sites, the magnitude of subsidence $(<60 \mathrm{~mm})$ and the lack of full ground recovery and/or prolonged ground recovery at many levelling stations. The months during which the most significant and rapid subsidence occurred (June and July) coincided with the peak transpiration periods of deciduous trees (Thomas, 2000). Verticality surveys carried out on expansive clays away from vegetation typically record subsidence in the range of 10-20mm (Lawson, 2000). Clay-rich soil subsidence due solely to the seasonal effects of summer are commonly reported as being restricted to the upper $1.5 \mathrm{~m}$ below ground level where field capacity (and therefore ground recovery) is quickly re-established (Biddle, 1998, Smethurst, 2006).

\subsection{Electrical Resistivity Tomography (ERT) data}

\subsubsection{Willow Site Data - Results and Interpretation}

The time-lapse resistivity difference models (Fig. 8) can be broadly sub-divided into three sequential divisions, each of which have characteristic changes in resistivity interpreted to be distinctive of a particular moisture content distribution regime/pattern (Table 3). These were most probably induced by both individual and cumulative seasonal effects and the water absorption of tree roots (Table 3 for detail).

\begin{tabular}{|c|c|c|}
\hline $\begin{array}{l}\text { Cat } \\
\text { No }\end{array}$ & ERT Results & ERT profile interpretation \& Support \\
\hline 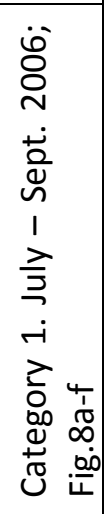 & $\begin{array}{l}\text { Category } 1 \text { profiles show a } \\
\text { shallow (<1.5m depth) laterally } \\
\text { extensive anomaly showing } \\
\text { increases in resistivity }<230 \% \text {, } \\
\text { relative to the March } 07 \\
\text { reference dataset. The anomaly } \\
\text { can be observed progressively } \\
\text { increasing in both lateral extent } \\
\text { (up to } 20.5 \mathrm{~m} \text { from the Willow) \& } \\
\text { resistivity magnitude throughout } \\
\text { the time period shown. }\end{array}$ & $\begin{array}{l}\text { Interpretation - Drying effects of the Willows } \\
\text { near surface root plate }\end{array}$ \\
\hline
\end{tabular}




\begin{tabular}{|c|c|c|}
\hline 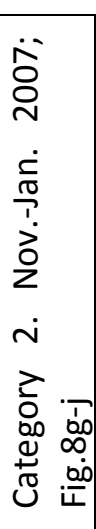 & $\begin{array}{l}\text { Category } 2 \text { profiles show an } \\
\text { overall decrease in near-surface } \\
\text { resistivity relative to the Category } \\
1 \text { differential models and } \\
\text { reference data. Several isolated } \\
\text { areas of increased resistivity at } \\
\text { depths below } 0.5 \mathrm{~m} \text { can be } \\
\text { observed, with the most } \\
\text { pronounced of these lying } \\
\text { directly beneath the Willow } \\
\text { canopy (Fig.g/h). }\end{array}$ & $\begin{array}{l}\text { Interpretation - Dissipation of drying caused by } \\
\text { the Willows near surface root plate. }\end{array}$ \\
\hline 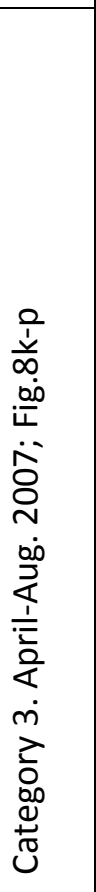 & $\begin{array}{l}\text { Category } 3 \text { differential images } \\
\text { show the development of two } \\
\text { laterally extensive anomalies of } \\
\text { resistivity increase <230\%, } \\
\text { located near the surface (up to } \\
1 \mathrm{~m} \text { BGL) and at a depth of } \\
\text { between } 2 \text { to } 4 \mathrm{~m} \text {. The shallow } \\
\text { feature is shown to extend up to } \\
15 \mathrm{~m} \text { from the Willow, whilst the } \\
\text { deeper lateral feature extends } \\
\text { the full length of the profile at } \\
\text { this depth. } \\
\text { Like the differential images } \\
\text { shown in Category 1, the } \\
\text { anomalies can be observed } \\
\text { progressively increasing in both } \\
\text { lateral extent \& resistivity } \\
\text { magnitude throughout the time } \\
\text { period shown. }\end{array}$ & $\begin{array}{l}\text { Interpretation - Drying effects of the Willows } \\
\text { near surface root plate and second root tier. }\end{array}$ \\
\hline
\end{tabular}

Table 2. Willow Time-Lapse ERT grouped profile observations and interpretations.

\section{Interpretation Discussion}

\section{Category 1 Interpretation - Drying effects of the Willows near surface root plate.}

Although general summer-related effects (e.g., increased temperature, evaporation \& grass transpiration) may partially result in an overall resistivity increase (indicative of clay desiccation \& near-surface drying), the anomaly shows features (both spatial and temporal) that are typically attributed to the drying caused by tree roots. These include;

- The spatial nature of the anomaly which consistently originates from the Willow and is highly characteristic of a typical Willow root system, comprised largely of extensive lateral roots (concentrated in the upper $1.5 \mathrm{~m}$ of soil), and occasional droppers (Gasson and Cutler, 1990).

- The progressive outward growth (both lateral and vertical) of the anomaly through time. This feature is interpreted to represent the subsequent effects of a tree roots common response to drought exposure, which is the production and rapid extensional growth of fine roots (particularly at the root plate periphery) in order to increase the volume of soil for water exploitation (Coder 1999, Biddle, 1998, Lawson, 2000, Thomas, 2000). 


\section{Category 2 Interpretation - Dissipation of drying caused by the Willows near surface root plate.}

Increased rainfall over the winter month and the seasonal inactivity of the Willow's fine moisture absorbing roots support this interpretation. The deep isolated high resistivity anomalies remaining are interpreted to represent zones suffering from a persistent soil moisture deficit (SMD). As such it can be suggested that the accumulative rainfall and/or the infiltration period was insufficient for the rehydration of clays at depth. This is deemed particularly so for the anomaly directly beneath the tree canopy where downward water infiltration is inhibited.

Category 3 Interpretation - Drying effects of the Willows near surface root plate and second root tier. Similarities in the spatial and temporal descriptions for the shallow anomaly shown in these profiles with those from Category 1, again suggest drying from the near surface root plate. The reduced lateral extent of the anomaly in theses images $(<15 \mathrm{~m})$ relative to those of Category $1(<20.5)$ are interpreted to reflect the dynamic response of shallow root absorption to changes in rainfall. Summer 2007 was much wetter than 2006 (Fig.5); therefore potentially reducing the lateral anomaly extent as the tree did not need to utilize a greater root expanse for its water demand. The reoccurrence of this anomaly over contrasting summer conditions supports the observed resistivity changes are a function of tree root absorption activity and not rainfall.

Fine root proliferation at depth is commonly cited as typical drought response behaviour to near-surface water stress (Lawson, 2000, Coder, 1999). The lateral anomaly occurring between 2 to $4 \mathrm{~m}$ deep may therefore be due to water uptake by dropper roots that had developed during the 2006 summer drought. The absence of significant drying at this depth during the 2006 summer (category 1 images) can be explained by the negligible effect on resistivity change when drying is first initiated. Laboratory research, undertaken on the electrical response of clays subjected to artificial drying (McCarter, 1984; Russell and Barker, 2004), indicates resistivity responses to moisture loss remain relatively static (or very small) until moisture loss reaches $60 \%$. Above $60 \%$, electrical resistivity increases rapidly and exponentially with further moisture loss. It can therefore be interpreted that during the 2006 summer, the initiation of moisture uptake and moisture loss at depth by roots was only enough to produce a very small response in resistivity, resulting in very minor resistivity changes at the time (see base of Fig.7a-f profiles).

\subsubsection{Comparison of Willow ERT and Levelling Data}

Trends in both the Willow ERT and levelling data were in very good agreement (Fig.9) and show that both subsidence and resistivity anomalies correspond with changing weather conditions. During the summer drought of 2006, the significant increases in both resistivity and the anomaly size were coupled with increases in subsidence indicated by levelling data. During the wetter autumn and winter of 2006, the dissipation of the high resistivity desiccation type anomalies were accompanied by levelling data that indicated swell. The lateral extent of significant drying indicated by the ERT differential images also match the lateral extent of significant subsidence in the levelling data over two summers despite the contrasts in rainfall (Fig.5). Peaks in subsidence during the summer of 2006 were spatially consistent and aligned with high resistivity ERT anomalies. The high resistivity anomalies observed during autumn and winter could finally also be spatially correlated with levelling trends, indicating residual summer subsidence and subsequent persistent soil moisture deficits. 


\subsection{Oak Site Data - Results \& Interpretation}

The time-lapse resistivity difference models (Fig. 10) can again be broadly sub-divided into sequential divisions, each of which have characteristic changes in resistivity interpreted to be distinctive of a particular moisture content distribution regime/pattern (Table 4). These were most probably induced by both individual and cumulative seasonal effects and the water absorption of tree roots (Table 4 for detail).

\begin{tabular}{|c|c|c|}
\hline $\begin{array}{l}\text { Time period \& } \\
\text { ERT no. }\end{array}$ & ERT profile description & ERT profile interpretation \\
\hline $\begin{array}{l}\text { 1. May - July } \\
\text { 2006; Fig.10a- } \\
\text { e }\end{array}$ & $\begin{array}{l}\text { Little evidence of a spatially or } \\
\text { temporally continuous anomaly } \\
\text { showing an increase in resistivity. }\end{array}$ & $\begin{array}{l}\text { Interpretations - } \\
\text { 1) Inactive Fine Root absorption due } \\
\text { to water stress/ drought conditions } \\
\text { and/ or } \\
\text { 2) Poor ERT imaging of the root zone } \\
\text { due to; a) High levels of noise b) 2D } \\
\text { Inversion Limitations c) Very small } \\
\text { resistivity contrasts c) The lag effects } \\
\text { which arise from the relationship } \\
\text { dynamics of moisture content change } \\
\text { and rates of resistivity change as } \\
\text { previously discussed. }\end{array}$ \\
\hline $\begin{array}{l}\text { 2. Aug.-Sept. } \\
\text { 2007; Fig.10f-i }\end{array}$ & $\begin{array}{l}\text { Laterally extensive anomalies } \\
\text { showing increases in resistivity } \\
<300 \% \text { can be observed near the } \\
\text { surface ( }<1 \mathrm{~m} \text { depth) and at a } \\
\text { depth between } 1.5 \mathrm{~m} \text { to } 4 \mathrm{~m} \text {. } \\
\text { Adjoining these levels, are a } \\
\text { series of vertically oriented high } \\
\text { resistivity features of the same } \\
\text { magnitude giving the appearance } \\
\text { of a relatively continuous (inter- } \\
\text { connected) spatial form. }\end{array}$ & $\begin{array}{l}\text { Interpretation - The effects of root } \\
\text { drying generated by a two-tiered } \\
\text { lateral root system exploiting water } \\
\text { from the near surface and gravel rich } \\
\text { clay bands situated at around } 2 \\
\text { metres depth. }\end{array}$ \\
\hline $\begin{array}{ll}\text { 3. Oct. } & \text { 06- } \\
\text { May. } & 07 ; \\
\text { Fig.10j-q } & \end{array}$ & $\begin{array}{l}\text { As Category } 2 \text { with evidence of } \\
\text { an overall decrease in resistivity. }\end{array}$ & $\begin{array}{l}\text { Interpretation - Widespread } \\
\text { persistent soil moisture deficits in the } \\
\text { spatial form of the Oaks two-tier root } \\
\text { system with minor dissipation in the } \\
\text { magnitude of drying relative to } \\
\text { previous images. }\end{array}$ \\
\hline $\begin{array}{l}\text { 4. June -Sept. } \\
\text { 07; Fig.10r-y }\end{array}$ & As Category 2. & $\begin{array}{l}\text { Interpretation - The effects of root } \\
\text { drying generated by a two-tiered } \\
\text { lateral root system exploiting water } \\
\text { from the near surface and gravel rich } \\
\text { clay bands situated at around } 2 \\
\text { metres depth. }\end{array}$ \\
\hline
\end{tabular}

Table 4. Monitoring Oak ERT grouped profile observations and interpretations

Interpretation Discussion 
The Oak Category 1 differential ERT images do not show a continuously increasing resistivity pattern (Table 3). This could be due to several factors. Research has shown that during droughts and dry periods, tree root systems can cease root absorption (Coder, 1999) and can preferentially exploit water at depth when there are limiting near-surface resources (Cameron, 2001, Coder, 1999, Thomas, 2000). Tree roots are also capable of hydraulic redistribution, a process, which is more recently being recognized as an important and major drought coping activity of tree roots (Burgess and Bleby, 2006, Leffler et a I , 2005, Hultine et $a l, 2004)$. Finally, tree leaves can close their stomata, thus restricting the water required from root absorption, in order to prevent transpiration and conserve water (Coder, 1999).

Whereas the Willow site shows a clear dissipation in high resistivity anomalies throughout winter, there is little change in the Oak site resistivity anomalies over time. Consequently, it is interpreted that active rehydration of the sub-surface proximal to the Oak tree is minimal and is, subsequently, suffering from a wide-spread persistent soil moisture deficit.

It should also be noted here that the Oak had lost significant portions of its crown on two occasions since monitoring began. Although the first of these incidents coincided with a period of high winds, it should be noted that either occurrence could be a result of dieback, (which is an expression of drought damage), or effective compartmentalization (a drought minimizing strategy) as shown by Coder (1999). It is therefore possible that the Oak is under greater water stress than the Willow, which may again suggest that the sub-surface in proximity to the Oak tree is suffering from a persistent soil moisture deficit. It can also indicate that there is a greater likelihood that the Oak tree is displaying the drought coping strategies discussed (i.e. root suberisation and stomatal closure) as the reason for the reduced water uptake shown by the ERT imagery and subsidence trends.

\subsubsection{Comparison of Oak ERT and Levelling Data}

Unlike the highly comparable Willow site ERT and levelling data trends, the Oak site high resistivity ERT anomalies and levelling data appear less comparable (Fig. 11). This is most likely attributed to the more heterogeneous soil stratigraphy at the Oak site soil as noted in Section 2. Drainage of water from structural pores and/or voids within gravel-rich clay would not be accompanied by significant volume change as would be experienced with a cleaner more homogeneous clay. This factor may therefore explain the poor data correlations and smaller ground movement magnitudes observed at the Oak study site. The heterogeneous ground may also have made the 2D ERT inversion models less reliable, which is often indicated by high RMS errors (Bentley and Gharabi, 2004, Panissod, et al, 2001). This was indeed the case, whereby RMS error for the Oak ERT inversions was $<50 \%$ in comparison to $<10 \%$ typical RMS error for the Willow models.

Despite poor comparisons in spatial ERT and levelling trends, there is a good comparison with the datasets regarding temporal trends, as both strongly suggest the occurrence of a wide-spread persistent soil moisture deficit at the Oak site. Differential ERT images and levelling data represent this respectively with; the constant occurrence of wide-spread high resistivity anomalies regardless of season and the lack of ground swell above the pre-2006 drought reference levels.

\subsubsection{Comparison of Oak ERT data and Soil Moisture Deficit (SMD) values}


Soil Moisture Deficits (SMD's) provide a useful indication on how dry the soil is by representing the quantity of water (expressed in terms of height $(\mathrm{mm})$ ) needed to return the soil to its normal saturation equilibrium (i.e., field capacity). Results show that the most significant deficits (those over $25 \mathrm{~mm}$, Biddle, 1998) occur at the near surface and most distinctly at a depth around $2 \mathrm{~m}$ for all neutron probes (Fig.12).

SMD's at the surface can be attributed to a combination of near surface seasonal effects and shallow root water absorption. The $\sim 2 \mathrm{~m}$ depth $S M D$, however, is unlikely to be due to nearsurface seasonal effects and shallow water absorption, if it was, the drying pattern would be vertically continuous and reducing in intensity from the surface downwards which is only shown by the NP2 probe. Soil moisture loss due to near surface effects and/or light vegetation is also commonly cited as being confined to the top 1-1.5 metres of soil (Ward, 1953; Driscoll, 1983; BRE Digest 240, 1993; Biddle, 1998; Smethurst, 2006). The 2m SMD's therefore can be attributed to water extraction by the tree roots. As such SMD data provide complementary evidence to validate the ERT interpretation of a two-tiered lateral root system as suggested. 


\section{Discussion}

\subsection{Willow and Oak site data differences}

Contrasts in the study site local soil and geology, tree age, maturity and species could be held accountable for the site data differences. Of these factors however, the local soil and geology was considered the most influential. A comparison of the levelling data from each TIS monitoring site (Fig.7) showed that there was a significant difference in accumulative vertical movement over time at each site. Both ground subsidence and swell occurred to a greater extent at the Willow site compared to the Oak site, suggested to be due to the far more homogeneous nature of the clay-rich soil at the Willow site which is supported by site investigation information (Fig.4). The presence of gravel rich-horizons at the Oak site effectively resulted in an overall reduced ground shrinkage potential as water removed from gravel and structural voids would not have been accompanied by any volume change.

Data from the Willow site also showed that where there is relatively homogeneous ground conditions, 2D ERT and levelling datasets can be in very good agreement, which bodes well for the ability of ERT to be used as a stand-alone TIS assessment tool. However, at significantly more heterogeneous ground conditions (such as the Oak study site), there was a less good comparison between the 2D ERT and levelling data, which could result in both spurious ERT inversion models and potentially spatially complex ground shrinkage patterns.

Nevertheless, it has been demonstrated that 2D ERT data at such complex sites can still provide a good indication of the overall tree root architecture and drying patterns, as highlighted by closely correlating spatial desiccation trends from both ERT and soil moisture deficit data.

\subsection{Willow and Oak site data similarities}

Despite the differences in study site soil and geology, tree species and age, there were distinct similarities in the spatial and temporal ground movement patterns and ERT anomaly trends from both the Oak and Willow study sites. Therefore, it could be suggested that a general root drying and subsidence pattern exists (amongst deciduous trees at least), that is governed by unifying water absorption behaviours and drought adaptive strategies. Figure 13 shows the data from which such a model could be derived and depicts that with each tree, two zones of movement could be delineated according to the lateral extent of their ERT-deduced, main root plate.

The Inner Movement Zone (IMZ): Radiated out to $11.5 \mathrm{~m}$ laterally from each studied tree. Significant subsidence in this area occurred despite the contrasts in summer rainfall over the two year monitoring period; coupled with laterally-dominant, high resistivity features that were spatially consistent over each summer. This supported the interpretation that the IMZ area was occupied by the main root plate. Also observed are two distinct peaks in summer subsidence that appeared either side of the tree, often accompanied by vertically oriented high resistivity features possibly representative of dropper root drying activity. The position of these features directly beneath the canopy drip zone suggests that roots exploit this water source.

The Outer Movement Zone (OMZ): Experienced very variable summer ground subsidence trends. During the 2006 summer, subsidence was very high, exceeding all values experienced 
in the IMZ; whilst during the 2007 summer, subsidence is particularly low and below that of the IMZ, where the subsidence is most dominant. The corresponding ERT imagery showed that during the 2006 summer, there was a significantly greater lateral extent in the shallow, near-surface, laterally-dominant ERT anomaly. The most plausible explanation for these data trends was the elongation of fine moisture absorbing roots at the root plate periphery, which is a common root response to water stress (Coder, 1999, Thomas, 2000). Subsidence maximums at the root plate periphery and an increased lateral root extent was interpreted via ERT imagery and could therefore be accountable through such root behaviour. It should be noted that the exploitation of water reserves in this way can cause not only sudden, but high levels of subsidence movement. This is due to the large uptakes of water from clays of greater shrink-swell potentials relative to those within the IMZ, which suffered from both persistent deficits and hysteretic effects which significantly suppresses their subsidence potential.

The delineation of movement zones from the monitoring data as described above can be used to provide a general indication on spatial subsidence patterns in the future. During droughts, root elongation behaviour will result in major ground subsidence in the $\mathrm{OMZ}$, whilst during wet summers, subsidence will be restricted to occurring within the main root plate. Therefore in summary, the $\mathrm{OMZ}$ can be defined as the area to which tree-related drought responses result from fine root elongation and absorption at the main root plate periphery, whilst the IMZ broadly defines the area occupied by the bulk of the root zone (main root plate extent) which is well established and more static. Localized subsidence hotspots within each zone can be classified according to those that are constant throughout the summer seasons (i.e. beneath the canopy drip-line) and/or dynamic according to the summer conditions (i.e. at the periphery of the supposed main root plate during droughts).

Further laboratory research is currently ongoing to acquire resistivity measurements from different percentage clay models that are subjected to controlled drying. Preliminary laboratory data indicates that resistivity can be linearly correlated with clay shrinkage during the first stages of desiccation. From this work, it may be possible to determine resistivitybased evaluations on likely moisture conditions from sampled sites from which the subsidence potential could then be quantified.

\section{Implications for current TIS guidelines}

The results from this TIS monitoring study show that highly localised ground subsidence can occur at varied and significant vertical and lateral distances from deciduous trees in seasonal climates, where site conditions permit optimum root growth and proliferation, the likelihood of which, is exacerbated during drought conditions. ERT and levelling data cross-correlations show that revisions to current Building Research Establishment (BRE) and National House Building Council (NHBC) guidelines on tree-root drying patterns and foundation recommendations are needed. The recognition of subsidence hotpots that occur beneath the canopy drip-line and at the periphery of the main root plate is the key to this improved understanding.

The understanding of ground movement patterns associated with tree moisture uptake in clay-rich soils could be significantly improved using ERT techniques. Ground subsidence magnitude and spatial distribution is governed by site-specific conditions but ERT can yield an improved and more comprehensive understanding of site specific, sub-surface tree-clay moisture dynamics. Comparing the time-lapse ERT datasets and precise levelling data showed a good correlation of ERT desiccation-type resistivity anomalies with identified 
subsidence hotspots. The ERT method also has the advantage of tracking the dynamic responses of trees root systems to changing and extreme weather conditions, a feature which is made apparent from data collected over contrasting summers.

During the summer drought of 2006, ERT data showed the lateral extent and magnitude of drying ground caused by tree roots was significantly greater (laterally) than during the wetter summer of 2007. This spatial pattern was also evident in the levelling profiles where the lateral extents of vertical movement during both summers were in very good agreement with the ERT desiccation anomalies. ERT data alone may therefore enable spatial predictions of future movements during droughts, but it must be noted that quantitative subsidence predictions are governed by the shrink-swell potentials of the site-specific clays, the occurrence of soil moisture deficits and tree-specific factors such as tree maturity and species type.

\section{Conclusions}

The results presented in this paper confirm that ERT is a valuable and potentially effective technique in imaging the time-varying, near-surface moisture distribution around mature trees in expansive clay soil types. The technique has been shown in this study to define the spatially and temporally variable extent and general architecture of tree root zones through their effect on ground moisture.

ERT results correlate well with the conventional levelling, site investigation and neutron probe datasets confirming the technique's application for Tree Induced Subsidence assessment in these demanding site environments.

The ERT technique can provide a comprehensive image of site-specific soil and geological heterogeneities, the soil structure and moisture distribution, compositionally, spatially and temporally. Acquiring all this geotechnical information can significantly and quantitatively aid the identification of tree root resource exploitation and the associated potential ground subsidence zones. Overall the method reveals promising potential in aiding the assessment of TIS by yielding results which enable a greater understanding of the dynamics associated with the phenomena. 


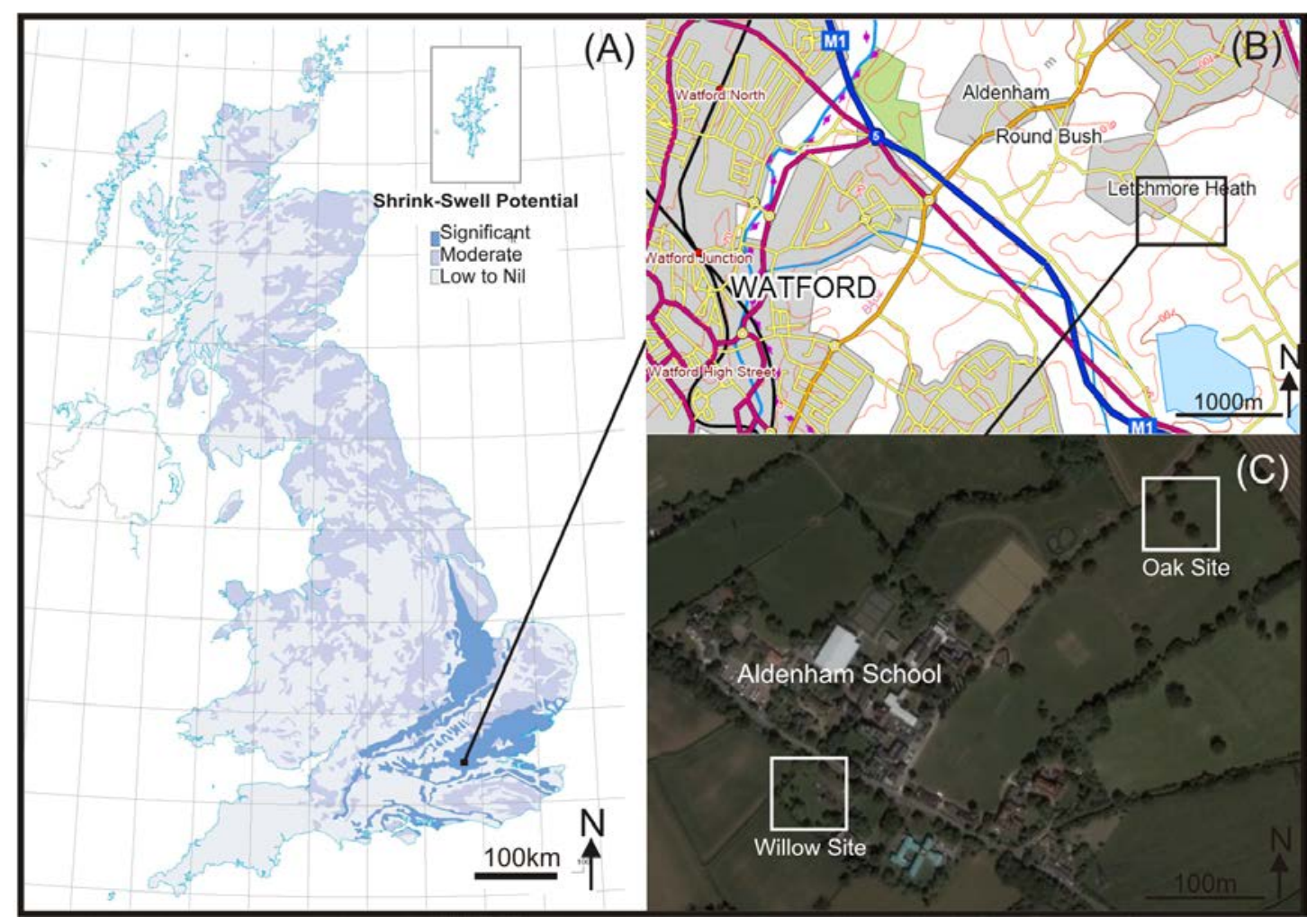

Figure 1 (A) UK soil swell-shrink potential map (courtesy of the British Geological Survey); (B) Site location map and; (C) Willow (lower) and Oak (upper) Monitoring Sites. (C) EDINA Digimap.
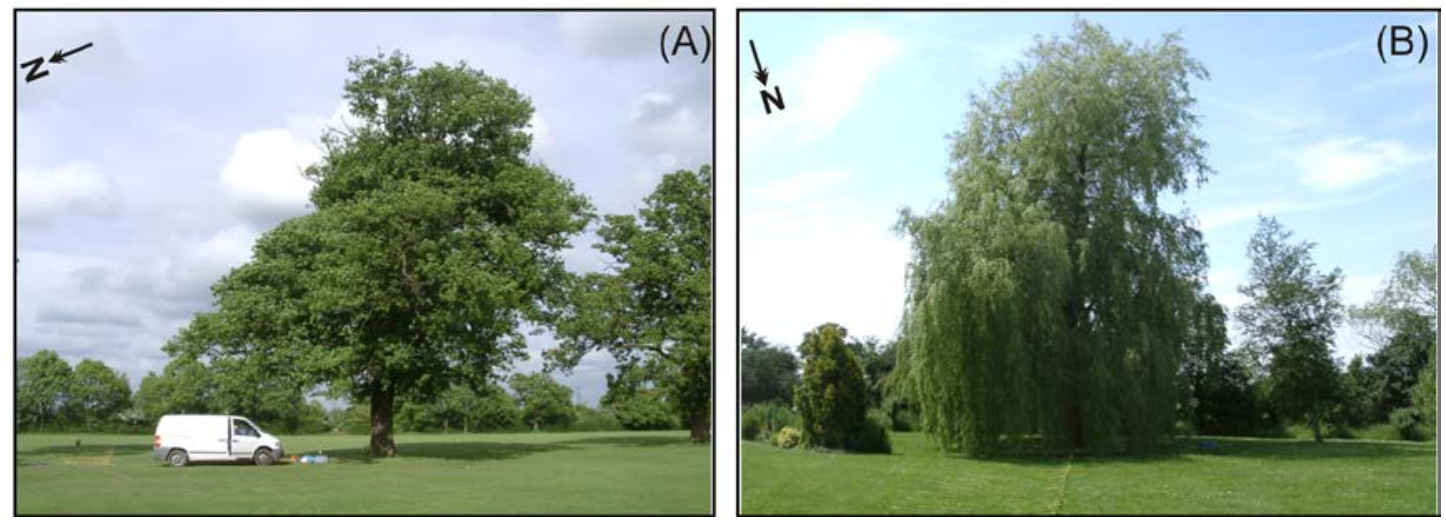

Figure 2 (A) Oak Tree and (B) Willow Trees Under Study. 


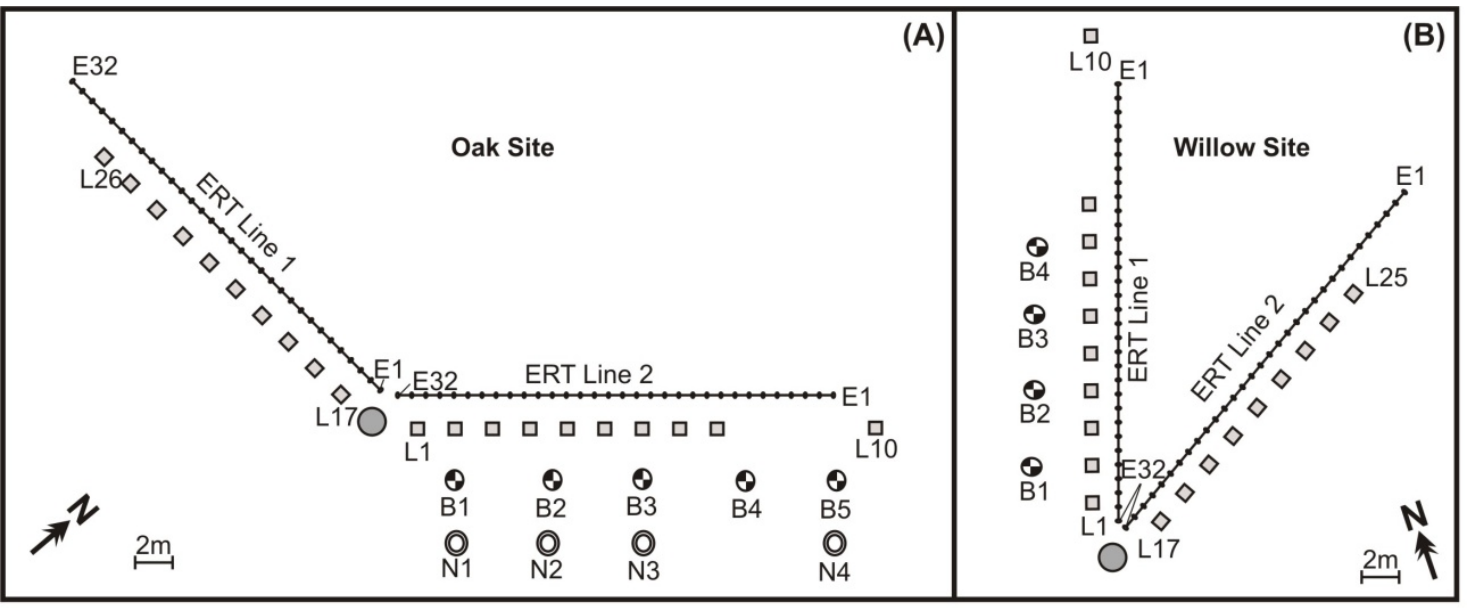

Tree ….. ERT Line a Levelling Stations () Neutron Probe Monitoring Wells @ Boreholes (May 2006) Figure 3 Instrumentation Layouts for the Oak Site (A) and (B) Willow Site showing ERT arrays, Levelling stations, Neutron probe monitoring wells and May 2006 Borehole positions.

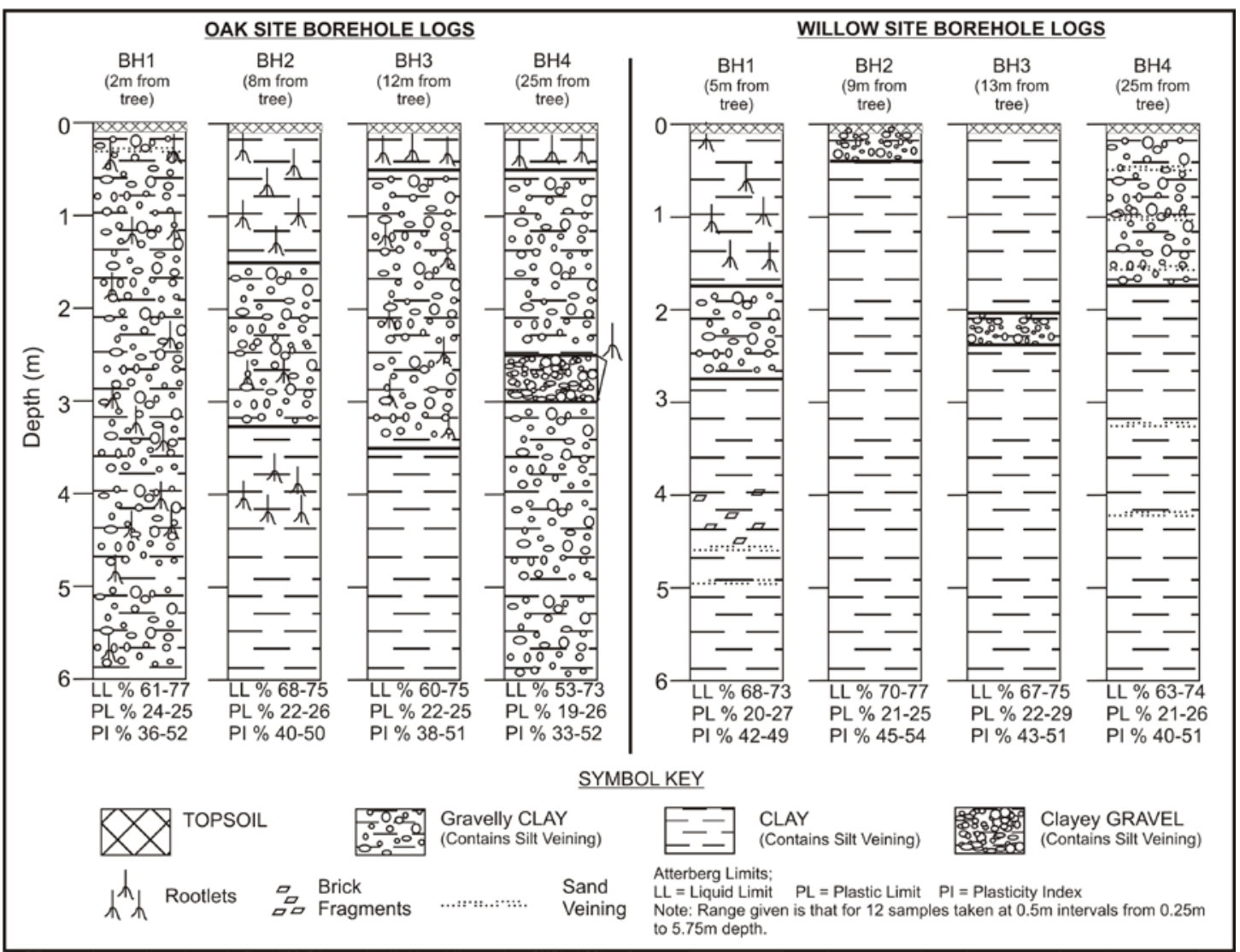

Figure 4. Borehole soil/ stratigraphy profiles and laboratory-measured Atterberg Limits for Oak Site and and Willow site (Fig.3 for location). 


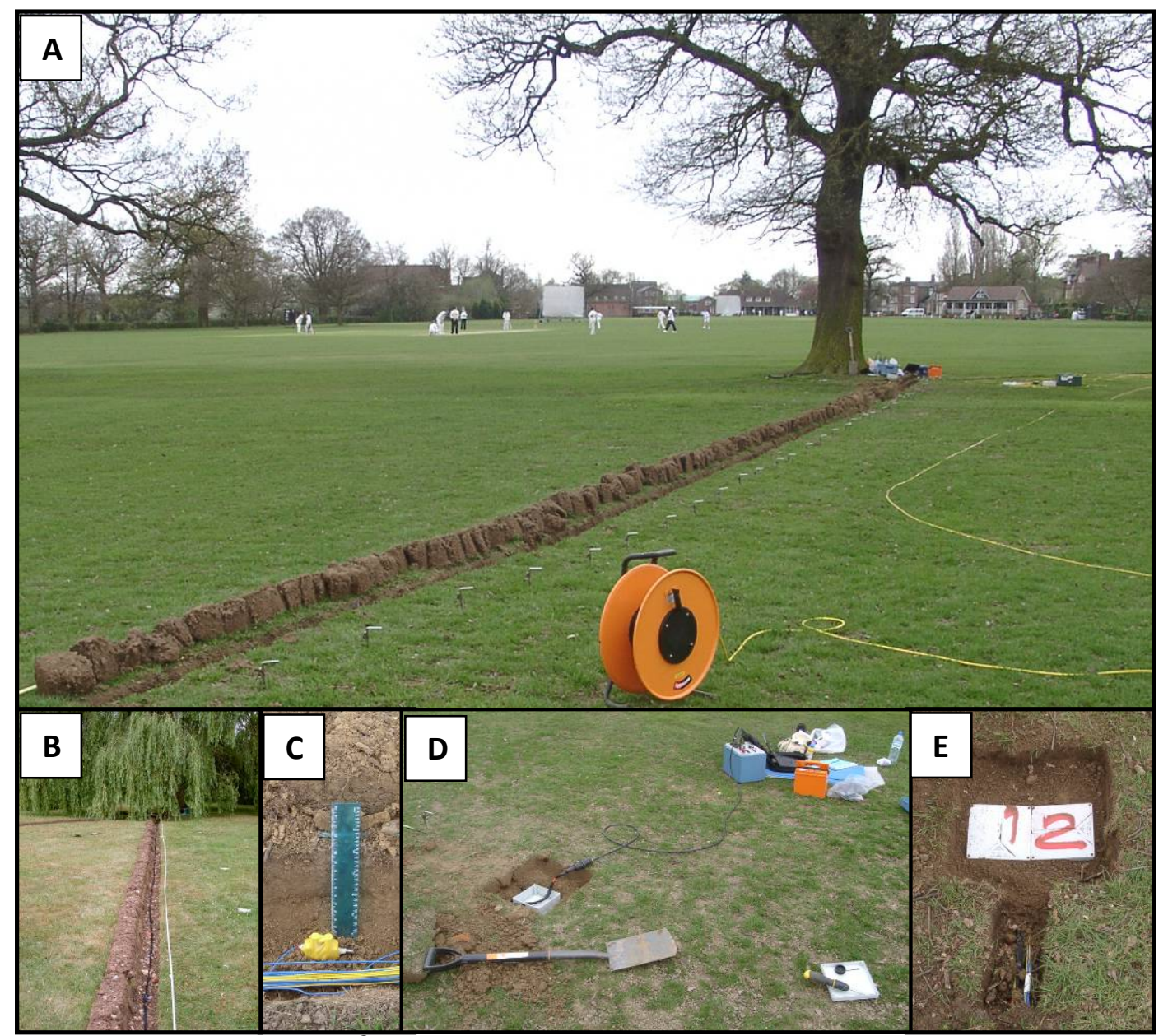

Figure 5. Photographs of Willow and Oak Site Permanent ERT Installation.

(A) Oak Line 2 ERT Installation; (B) Willow Line 1 ERT Installation; (C) Oak ERT Line 2 Electrode and cables; (D) Oak ERT Data Acquisition (E) Oak ERT Line 1 \& 2 Cable Output Junction Boxes. 


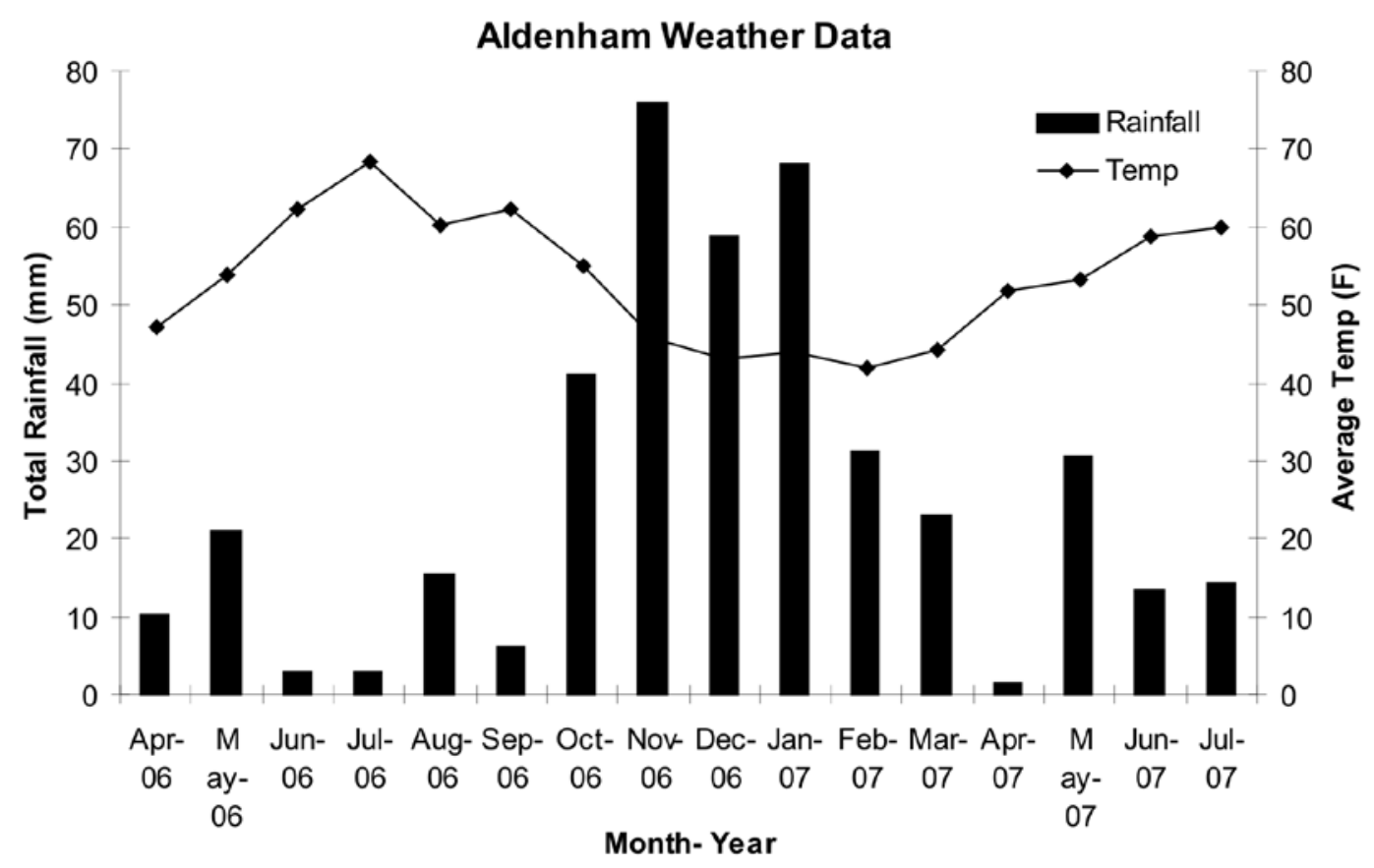

Figure 6. Summary temperature and rainfall data for the study sites during monitoring. 


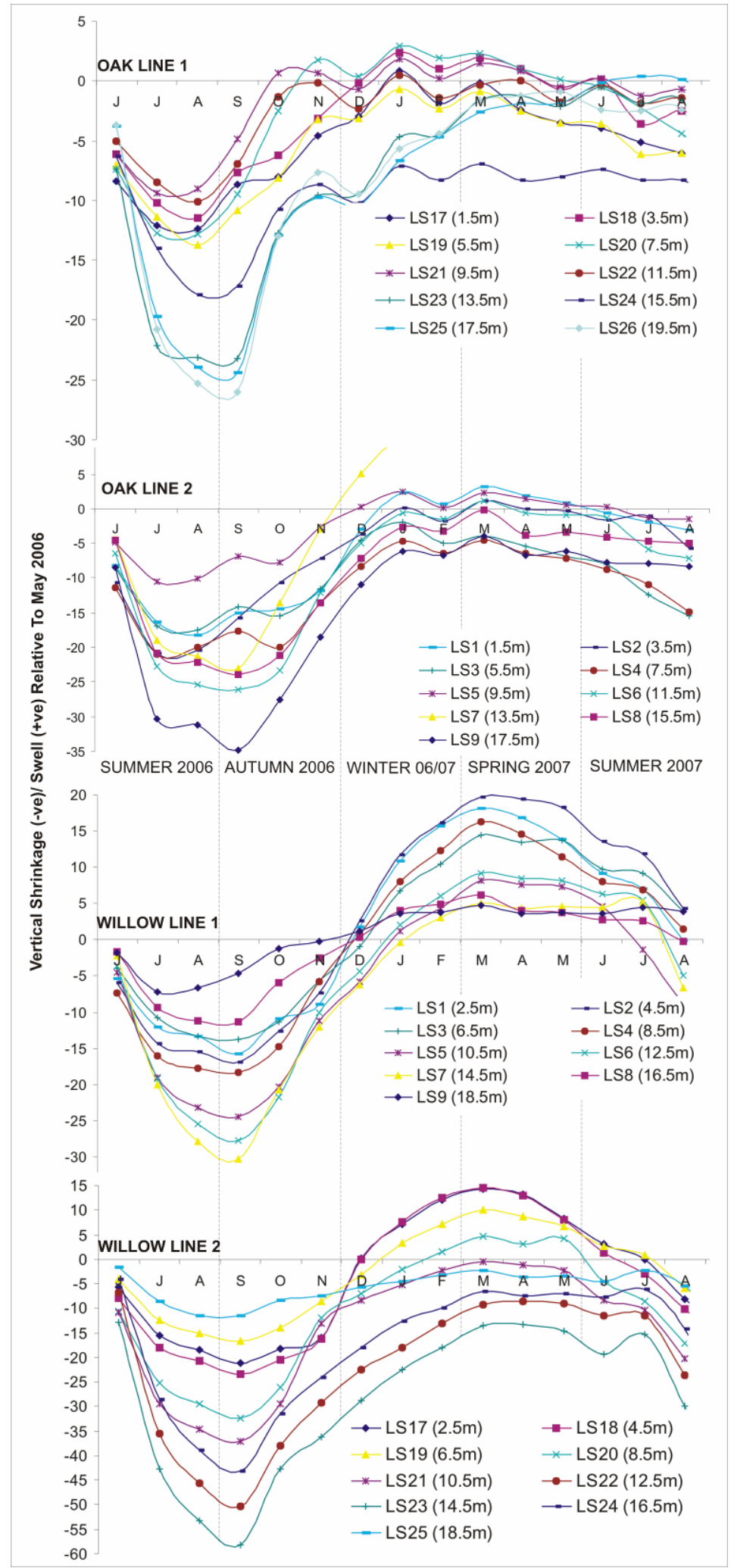

Figure 7. Precise levelling data $(\mathrm{mm})$ from June 2006 to June 2007 for the Oak and Willow sites relative to May 2006 readings. LS indicates Level Station, number in brackets gives tree distance. 


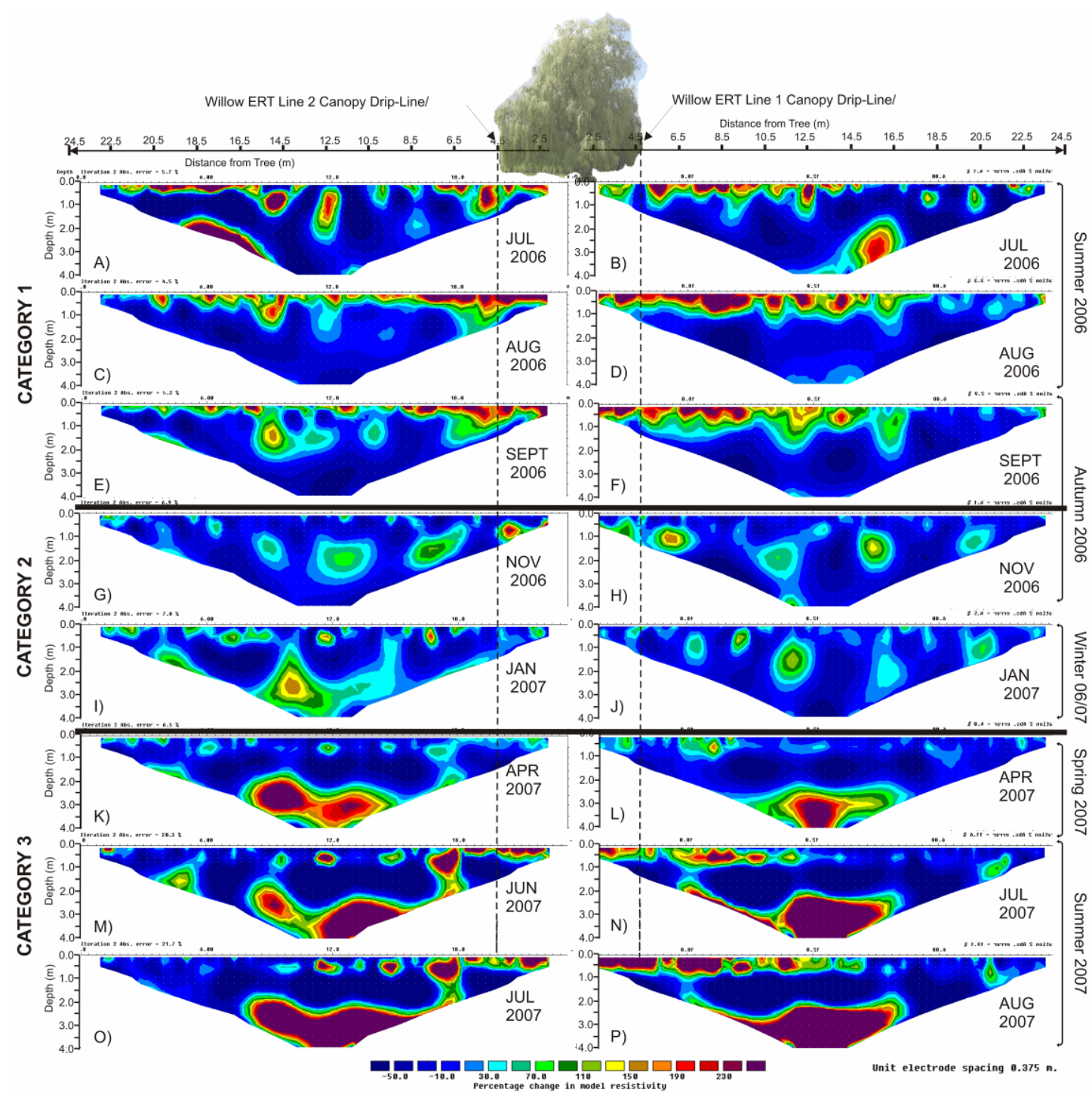

Figure 8. Time-lapse ERT models for Willow Line 1 (right) and 2 (left). Percentage change in resistivity were relative to the March 2007 reference dataset. Note contour scale were the same for all profiles. 


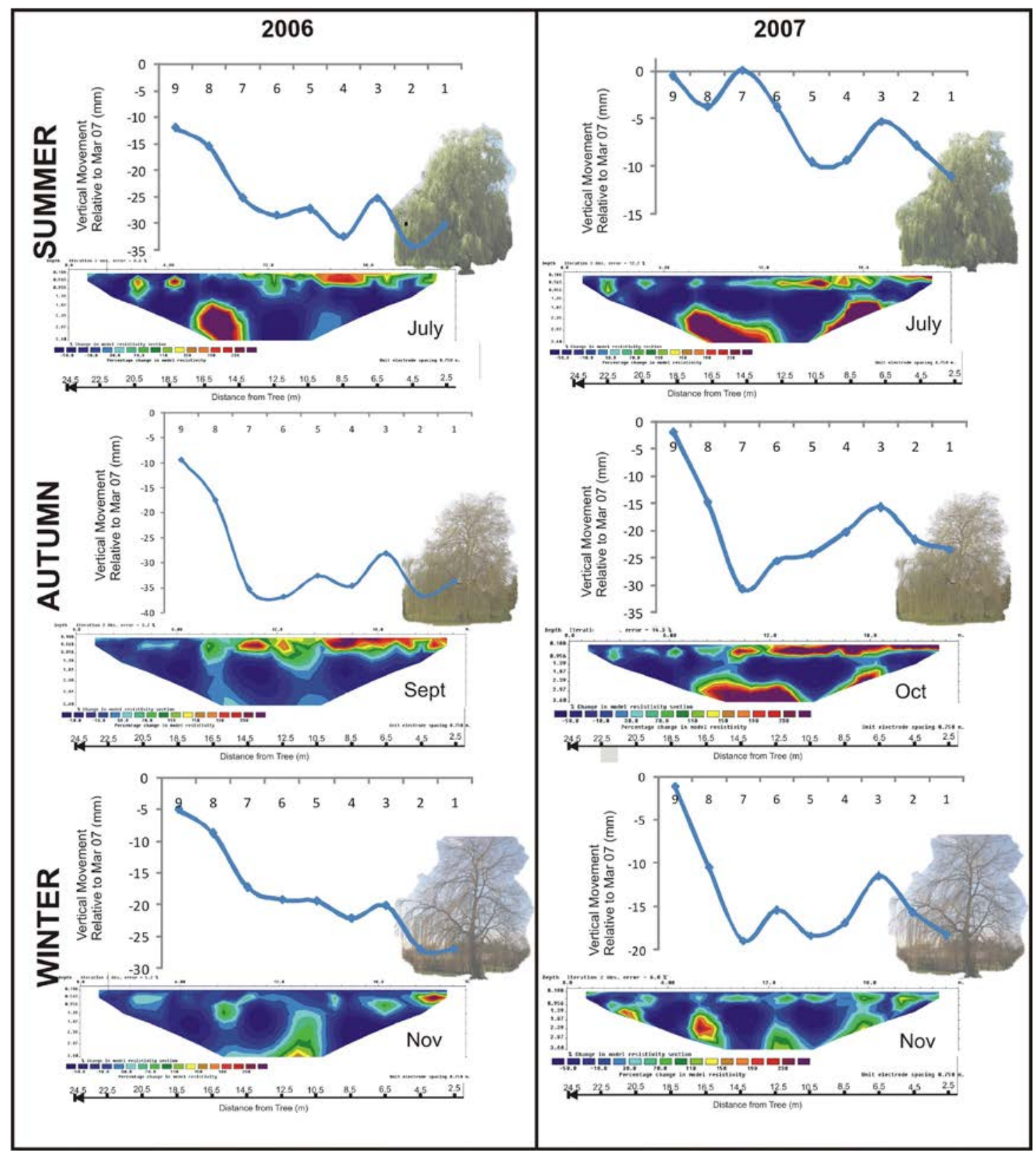

Figure 9 Comparison of Willow Line 1 Seasonal Time-Lapse ERT and Levelling datasets. NB: Model refinement not utilised. 


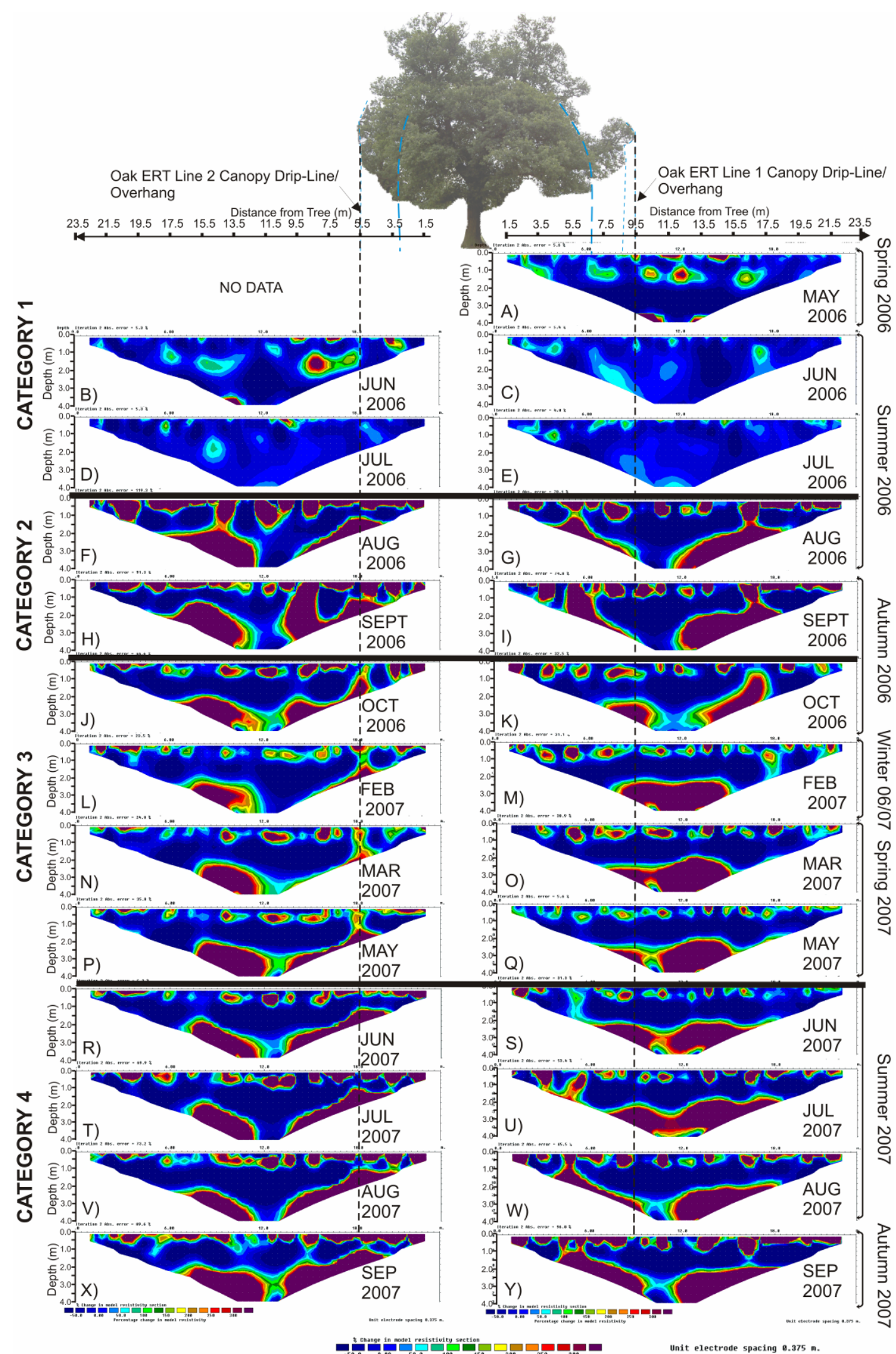

Figure 10 Time-lapse ERT models for Oak Line 1 (right) and 2 (left). Percentage changes in resistivity were relative to the March 2007 reference dataset. Note contour scale is the same for all profiles. 


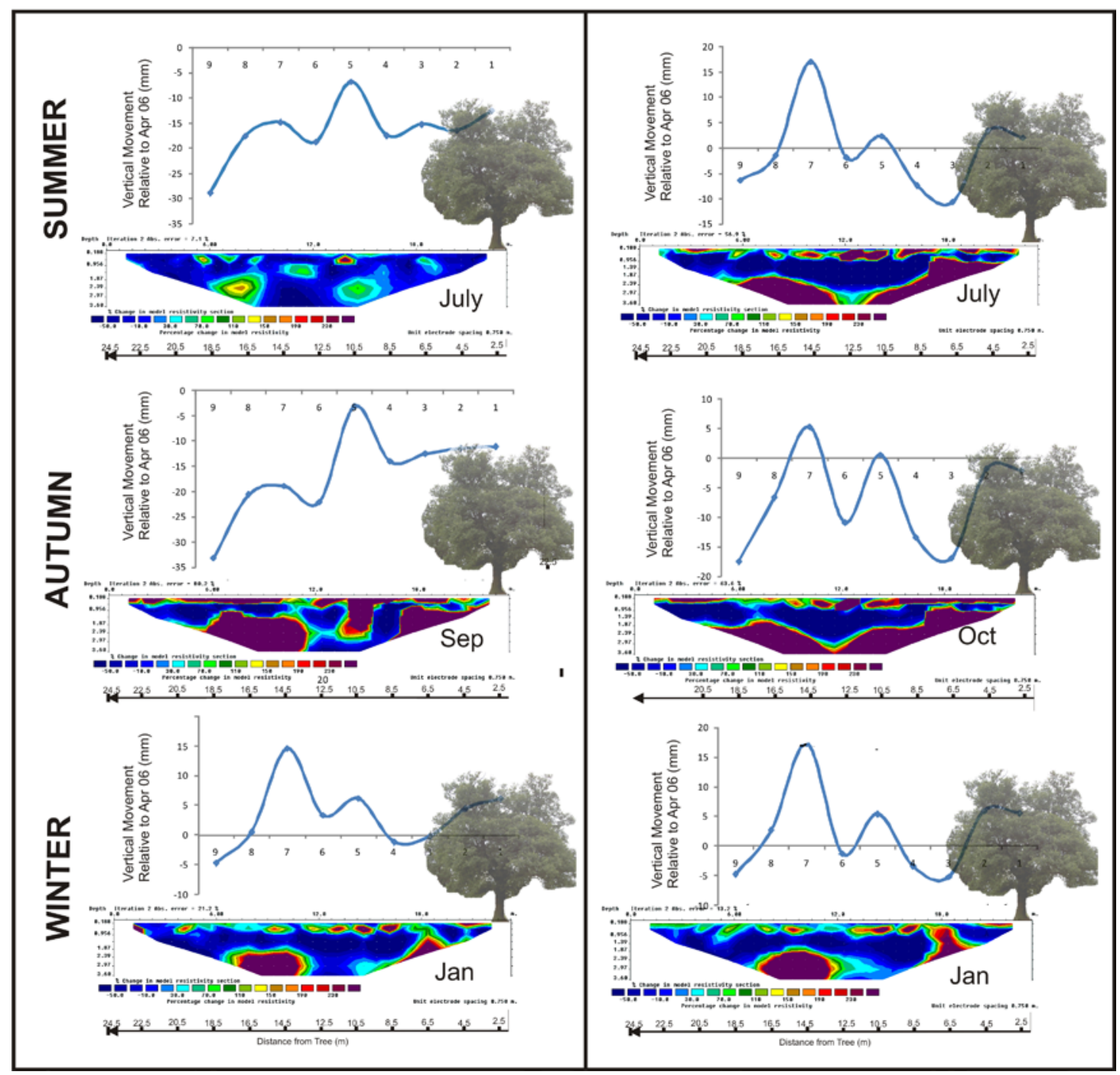

Figure 11. Comparison of Oak Line 2 ERT and Levelling Data datasets 


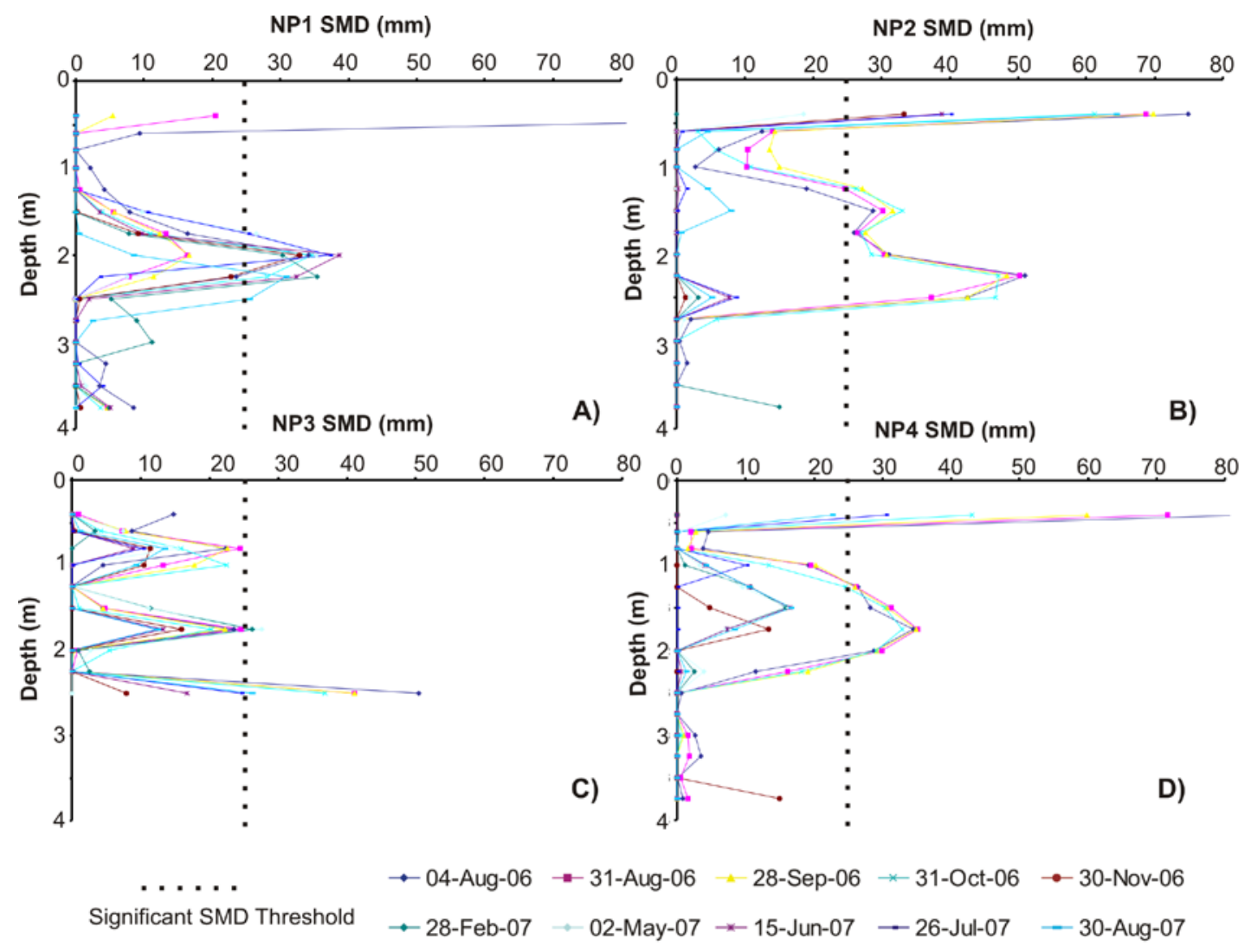

Figure 12 Soil Moisture Deficit (SMD) Profiles obtained from Neutron probe 1 (A), 2 (B), 3 (C) and 4 (D)., see Fig. 2 for location Dotted line at $25 \mathrm{~mm}$ indicates the threshold for significant deficits (Biddle, 1998). 

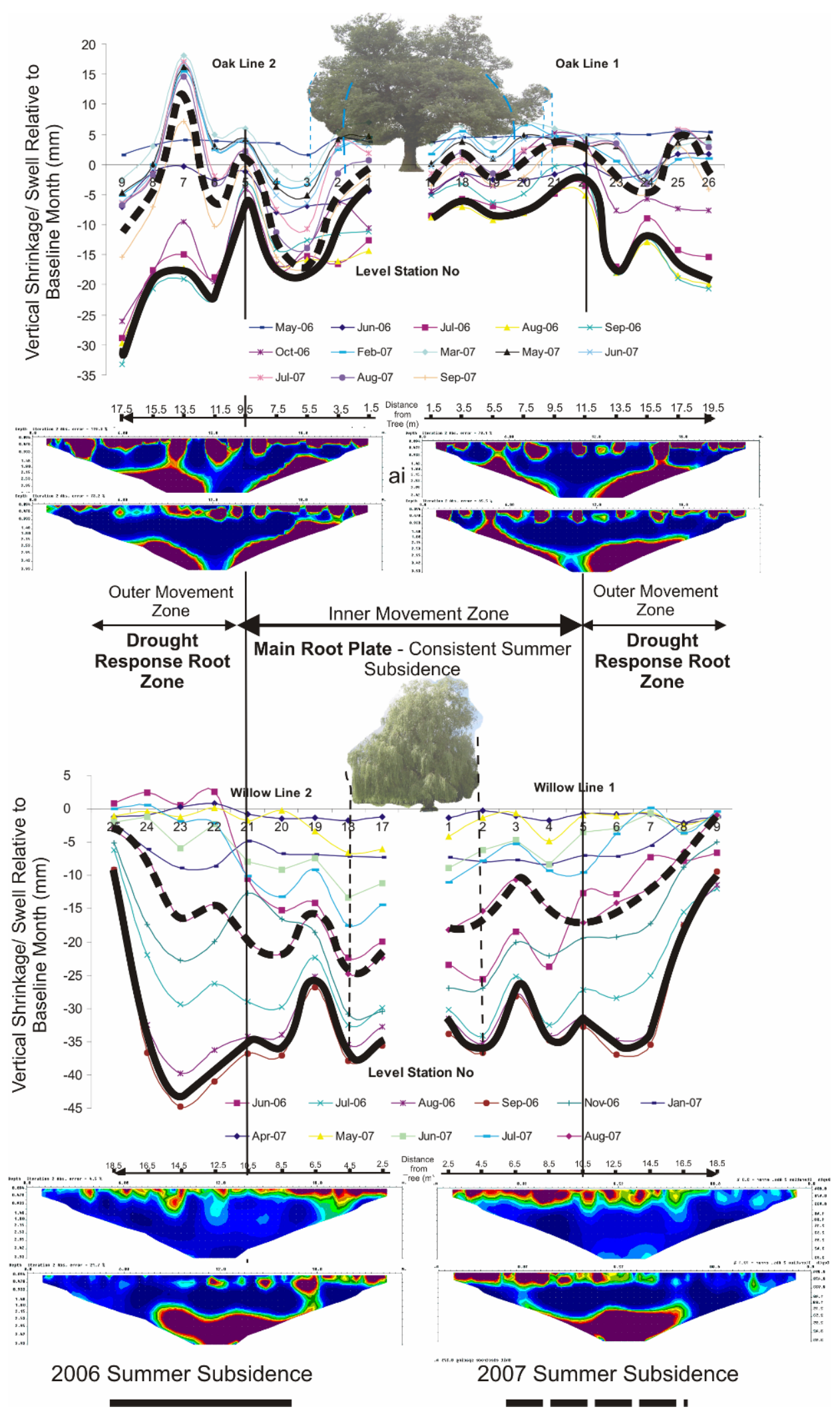

Figure 13 Interpreted site model showing Summer Inner and Outer Movement Zones (see text). 


\section{REFERENCES}

Bentley, L.R. and Gharibi, M. 2004. Two-and three-dimensional electrical resistivity imaging at a heterogeneous remediation site. Geophysics 69, No.3 pp674-680.

Biddle, P. G. 1998. Tree root damage to buildings. Volume 1 Causes, Diagnosis and Remedy. Willowmead Publishing Ltd. Wantage UK.

Binley, A., Shaw, B., Henry-Poulter, S. 1996. Flow pathways in porous media: electrical resistance tomography and dye staining image verification. Meas. Sci. Technol. 7, 384-390.

Building Research Establishment Digest 240. 1980. Low-rise buildings on shrinkable clay soils: Part 1. New Edition 1993.

Burgess, S.S.O. and Bleby, T.M. 2006. Redistribution of soil water by lateral roots mediated by stem tissues. Journal of Experimental Botany, Vol. 57, No.12, pp. 3283-3291

doi: 10.1093/ jxb/erl085 Advance Access publication 22 August, 2006

Cameron, D.A. 2001. The extent of soil desiccation near trees in a semi-arid environment. Geotechnical and Geological Engineering 19, pp357-370.

Coder, K. 1999. Drought Damage to Trees. University of Georgia School of Forest Resources Extension Publication for 99-010. 4/1999.

Dahlin, T. 2000. Short note on electrode charge-up effects in DC resistivity data acquisition using multi-electrode arrays. Geophysical Prospecting, 48, pp181-187

Dannowski, G., Yaramanci, U., 1999. Estimation of water content and porosity using radar and geoelectrical measurements. Eur. J. Environ. Eng. Geophys. 4, 71-85.

Driscoll, R. 1983. The influence of vegetation on the swelling and shrinking of clay soils in Britain.Geotechnique Vol 33, No 2, pp 93-105

Gasson, P.E. and Cutler, D.F. 1990. Tree Root Plate Morphology. Arboricultural, Vol 14, No 3, pp 193-264.

Habberjam, G. M. 1972. The effects of anisotropy on square array resistivity measurements. Geophysical Prospecting., 20, 249-266.

Hultine, K.R., Scott, R.L.Cable, W.L., Goodrich, D.C. and Williams, D.G. (2004) Hydraulic redistribution by a dominant, warm-desert phreatophyte: seasonal patterns and response to precipitation pulses. Functional Ecology, 18, pp 530-538

Jones, L. 2004. Cracking open. Planet Earth Autumn 2004 - www.nerc.ac.uk pp 30

LaBrecque, D., Sharpe, R., Wood, T., Heath, G. 2004. Small-Scale Electrical Resistivity Tomography of Wet Fractured Rocks. Ground Water, Vol 42, No 1 pp 1-8. 
Leffler, J.A., Peek, M.S., Ryel, R.J., Ivans, C. Y. and Caldwell, M.M. 2005. Hydraulic redistribution through the root systems of senesced plants. Ecology, Vol 86, Issue 3, pp633642.

Liu,S. and Yeh, T.J. 2004. An Integrative Approach for Monitoring Water Movement in the Vadose Zone. Vadose Zone Journal 3. pp681-692

Loke, M.H., and Barker, R.D. 1996. Rapid least-squares inversion of apparent resistivity pseudosections by a quasi-Newton method. Geophysical Prospecting, 44: 131-152

Loke M.H. 1999. Time-lapse resistivity imaging inversion. Proceedings of the fifth Meeting of the Environmental and Engineering Geophysical Society European Section, 1999.

Loke, M.H. 1999-2001. Electrical Imaging Surveys for Environmental and Engineering Studies. A practical Guide to 2-D and 3-D Surveys. Copyright (1997-2001) by Dr. M.H.Loke

McCann, D.M, Eddleston, M., Fenning, P.J. \& Reeves, G.M. (eds) 1997. Modern Geophysics in Engineering Geology. Geological Society Engineering Geology Special Publication No.12, pp334.

McCarter, W.J. 1984. The electrical resistivity characteristics of compacted clays. Geotechnique, Vol 34, No 2, pp 263-267.

McCarthy, J.J., Canziani, O.F., Leary, N.A., Dokken, D.J., White, K.S. 2002. Climate Change 2001; Impacts, Adaptation, and Vulnerability.

Cambridge University Press, Cambridge U.K.

Milson, 2004. Field Geophysics.

Panissod, O.C., Michot, D., Benderitter, Y. and Tabbagh, A. 2001. On the effectiveness of 2D electrical inversion results: an agricultural case study. Geophysical Prospecting 49 (5), pp570-576, 2001.

Reynolds, J.M. 2001. An Introduction to Applied and Environmental Geophysics. John Wiley \& Sons Ltd, England.

Russell, E and Barker, R. 2004. Variation of clay resistivity with moisture loss. Proceedings of $10^{\text {th }}$ Annual Meeting of Environmental and Engineering Geophysics, Utrecht, XXX.

Smethurst, J.A., Clarke, D. and Powrie, W. 2006. Geotechnique 56, No. 8, pp523-537

Thomas, P. 2000. Trees: Their Natural History. Cambridge University Press. Cambridge, U.K.

Turesson, A. 2006. Water content and porosity estimated from ground-penetrating radar and resistivity. Journal of Applied Geophysics No 58 pp99-111

Wright,M. (2006).

Zume, J.T., Aondover, T. and Christenson, S. 2006. Subsurface Imaging of an Abandoned Solid Waste Landfill Site in Norman, Oklahoma. Ground Water Monitoring \& Remediation, 26, 2, 62-69. 